\title{
Antiangiogenic potentials of ahpatinins obtained from a Streptomyces species
}

\author{
JANG MI HAN $^{1 *}$, JUN-PIL JANG $^{2 *}$, JAE-HYUK JANG $^{3,4}$, JONG SEOG AHN $^{2,4}$ and HYE JIN JUNG ${ }^{1,5,6}$ \\ ${ }^{1}$ Department of Life Science and Biochemical Engineering, Sun Moon University, Asan, \\ South Chungcheong 31460; ${ }^{2}$ Anticancer Agent Research Center and ${ }^{3}$ Natural Medicine Research Center, \\ Korea Research Institute of Bioscience and Biotechnology, Cheongju, North Chungcheong 28116; \\ ${ }^{4}$ Department of Biomolecular Science, KRIBB School of Bioscience, Korea University of Science and Technology (UST), \\ Daejeon 34141; ${ }^{5}$ Genome-based BioIT Convergence Institute; ${ }^{6}$ Department of Pharmaceutical Engineering \\ and Biotechnology, Sun Moon University, Asan, South Chungcheong 31460, Republic of Korea
}

Received July 19, 2019; Accepted December 6, 2019

DOI: $10.3892 /$ or.2019.7446

\begin{abstract}
While exploring new angiogenesis inhibitors from microbial metabolites, we recently isolated ahpatinins $\mathrm{C}$, E, and G from a soil-derived Streptomyces sp. 15JA150. Ahpatinins $\mathrm{C}, \mathrm{E}$ and $\mathrm{G}$ are known to have pepsin and renin inhibitory activities; however, their antiangiogenic activities and underlying molecular mechanisms have not been fully elucidated. In the present study, the antiangiogenic properties of ahpatinins $\mathrm{C}, \mathrm{E}$ and $\mathrm{G}$ were investigated. The results revealed that the natural compounds significantly inhibited the vascular endothelial growth factor (VEGF)-induced proliferation, invasion, adhesion, and tube formation of human umbilical vein endothelial cells (HUVECs) without exhibiting any cytotoxicity. It was also revealed that ahpatinin $\mathrm{E}$ effectively suppressed the neovascularization of the chorioallantoic membranes in growing chick embryos. Notably, ahpatinins C, $\mathrm{E}$, and $\mathrm{G}$ led to the downregulation of VEGF-induced activation of VEGF receptor 2 (VEGFR2) and its downstream signaling mediators, including AKT, ERK1/2, JNK, p38, and NF- $\kappa \mathrm{B}$, in HUVECs. Moreover, they reduced the expression of matrix metalloproteinase (MMP)-2 and MMP-9 in the HUVECs following stimulation with VEGF. Furthermore, ahpatinins $\mathrm{C}$,
\end{abstract}

Correspondence to: Professor Hye Jin Jung, Department of Life Science and Biochemical Engineering, Sun Moon University, 70, Sunmoon-ro 221, Tangjeong-myeon, Asan, South Chungcheong 31460, Republic of Korea

E-mail: poka96@sunmoon.ac.kr

Dr Jong Seog Ahn, Anticancer Agent Research Center, Korea Research Institute of Bioscience and Biotechnology, 30, Yeongudanjiro, Cheongju, North Chungcheong 28116, Republic of Korea

E-mail: jsahn@kribb.re.kr

*Contributed equally

Key words: tumor angiogenesis, Streptomyces sp., ahpatinins, VEGFR2, HIF-1 $\alpha$
$\mathrm{E}$, and $\mathrm{G}$ reduced the tumor cell-induced invasion and tube forming abilities of HUVECs, as well as the expression of VEGF, by suppressing hypoxia-inducible factor-1 $\alpha$ (HIF-1 $\alpha)$ activity in U87MG glioblastoma cells. Collectively, the present findings indicated that ahpatinins $\mathrm{C}, \mathrm{E}$, and $\mathrm{G}$ may be used in anticancer therapy by targeting tumor angiogenesis through the inhibition of both VEGFR2 and HIF-1 $\alpha$ pathways.

\section{Introduction}

Angiogenesis is a physiological process through which new blood vessels are formed from the existing ones, requiring coordinated proliferation, migration, invasion, adhesion, and tube formation of endothelial cells (1). However, angiogenesis also plays a vital role in tumor growth and metastasis since tumor expansion depends on blood supply for the delivery of essential nutrients and oxygen $(2,3)$. Although several angiogenesis inhibitors are in clinical use, they often have adverse effects such as dysfunction of endothelial cells, cardiovascular toxicity, and treatment resistance (4-6). Therefore, new antiangiogenic agents are still required to effectively and safely treat angiogenesis-related diseases, including cancer.

Vascular endothelial growth factor (VEGF) is one of the most important regulators of angiogenesis, and anti-VEGF therapies have been approved by the US Food and Drug Administration (7-11). VEGF receptor 2 (VEGFR2), the primary receptor of $\mathrm{VEGF}$, acts as the major mediator of VEGF-induced angiogenesis signaling pathways such as AKT, mitogen-activated protein kinase (MAPK), and nuclear factor $(\mathrm{NF})-\kappa \mathrm{B}$. Consequently, the activation of these pathways leads to endothelial cell proliferation, migration, and eventually capillary tube formation (12). VEGFR2-dependent activation of AKT signaling regulates the survival, proliferation, permeability, and anti-apoptotic functions of endothelial cells (13-15). In addition, the members of MAPK cascades, extracellular signal-regulated kinase (ERK1/2), c-Jun NH2-terminal kinase (JNK), and stress-activated protein kinase-2 (p38) regulate endothelial cell proliferation, migration, and differentiation when stimulated by VEGF (16-18). In addition, VEGFR2 signaling induces $\mathrm{NF}-\kappa \mathrm{B}$ activation in endothelial cells, and 
the $\mathrm{NF}-\kappa \mathrm{B}$ pathway sequentially upregulates proangiogenic and proinflammatory gene expression such as VEGF and tumor necrosis factor (TNF)- $\alpha$ (19). The binding of VEGF to VEGFR2 also activates the secretion of matrix metalloproteinase (MMP)-2 and MMP-9 for extracellular matrix (ECM) degradation in endothelial cells (20).

Moreover, rapid tumor expansion induces a hypoxic state inside the tumor, and in turn stimulates hypoxia-inducible factor (HIF)-1 $\alpha$, which is considered a master regulator of angiogenesis in hypoxia (21). HIF-1 is a heterodimeric transcription factor composed of two subunits, HIF-1 $\alpha$ and HIF-1 $\beta$. HIF-1 $\alpha$ is the key regulatory component of hypoxic responses. The HIF-1 complex recognizes a consensus hypoxia response element (HRE) in the promoter region of a broad range of target genes that mediate hypoxic response, including angiogenesis. However, the aberrant activation of HIF-1 $\alpha$ causes the overexpression of VEGF and tumor angiogenesis $(22,23)$. Therefore, dual inhibition of VEGFR2 and HIF-1 $\alpha$ activities could be a major strategy for the treatment of hypervascular tumors.

Microorganism-derived products, including proteins, enzymes, immunotoxins, and secondary metabolites, have been studied for cancer and other angiogenesis-related diseases (24-26). Recently, ahpatinins C, E, and G were isolated from a soil-derived Streptomyces sp. 15JA150 (Fig. 1), which are known to have pepsin and renin inhibitory activities $(27,28)$. Ahpatinin $\mathrm{C}$, also called pepstatin A, is a potent inhibitor of aspartic proteinases, such as pepsin and cathepsins D and E (29). Previous studies have reported that several natural protease inhibitors have antiangiogenic activities. PIVL, a serine protease inhibitor isolated from Macrovipera lebetina venom, exhibited a strong antiangiogenic effect both in vitro and in vivo by blocking the adhesive function of integrins and increasing microtubule dynamic instability in human microvascular endothelial cells (30). Amblyomin-X, a serine protease inhibitor from Amblyomma cajennense tick, impaired VEGF-A-induced angiogenesis by interfering with platelet-endothelial cell adhesion molecule-1 (PECAM-1) expression (31). Furthermore, a cystatin F homolog obtained from the buccal glands of Lampetra morii, which can suppress the activity of $\mathrm{C} 1$ cysteine proteases, was revealed to inhibit the key steps of angiogenesis, such as proliferation, adhesion, migration, invasion, and tube formation of human umbilical vein endothelial cells (HUVECs) (32). However, the antiangiogenic activities and underlying molecular mechanisms of ahpatinins $\mathrm{C}, \mathrm{E}$, and $\mathrm{G}$ have not been fully elucidated. In the present study, the antiangiogenic effects and the mechanisms of action of ahpatinins $\mathrm{C}, \mathrm{E}$, and $\mathrm{G}$ were investigated. The present study demonstrated that ahpatinins $\mathrm{C}, \mathrm{E}$, and $\mathrm{G}$ potently inhibited VEGF-induced angiogenesis by suppressing both VEGFR2 signal transduction and HIF-1 $\alpha$ expression, indicating that these new natural products could be used in the treatment of angiogenesis-related diseases, including cancer.

\section{Materials and methods}

Materials. Ahpatinins C, E, and G were prepared at a concentration of $50 \mathrm{mM}$ using dimethyl sulfoxide (DMSO). In all experiments, the negative control groups were treated with equal volumes of DMSO. Fetal bovine serum (FBS) and minimum essential medium (MEM) were purchased from Invitrogen (Thermo Fisher Scientific, Inc.), and endothelial growth medium-2 (EGM-2) and antibiotics were obtained from Lonza Group, Ltd. Recombinant human VEGF, Matrigel, gelatin, and Transwell chamber systems were obtained from Koma Biotech, BD Biosciences, Sigma-Aldrich (Merck KGaA), and Corning Costar, Inc., respectively. Antibodies against VEGFR2 (230 kDa; cat. no. 2479), phospho-VEGFR2 (Tyr1175, 230 kDa; cat. no. 2478), AKT (60 kDa; cat. no. 9272), phospho-AKT (Ser473, $60 \mathrm{kDa}$; cat. no. 9271), ERK1/2 (42, $44 \mathrm{kDa}$; cat. no. 9102), phospho-ERK1/2 (Thr202/Tyr204, 42, $44 \mathrm{kDa}$; cat. no. 9101), JNK (46 kDa; cat. no. 9252), phospho-JNK (Thr183/Tyr185, $46 \mathrm{kDa}$; cat. no. 9251), p38 (43 kDa; cat. no. 9212), phospho-p38 (Thr180/Tyr182, 43 kDa;

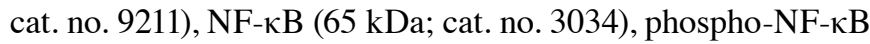
(Ser536, $65 \mathrm{kDa}$; cat. no. 3033), MMP-2 (64, $72 \mathrm{kDa}$; cat. no. 4022), MMP-9 (84, $92 \mathrm{kDa}$; cat. no. 3852), HIF-1 $\alpha$ (120 kDa; cat. no. 79233), $\beta$-actin (42 kDa; cat. no. 4967), rabbit IgG (cat. no. 7074), and mouse IgG (cat. no. 7076) were purchased from Cell Signaling Technology, Inc.

Fermentation, extraction, and purification of ahpatinins $C$, $E$, and $G$. Streptomyces sp. 15JA150 was cultured in a $250-\mathrm{ml}$ Erlenmeyer flask containing $50 \mathrm{ml}$ of seed culture medium for 3 days at $28^{\circ} \mathrm{C}$ on a rotary shaker with agitation at $125 \mathrm{rpm}$. For a large culture, $1 \%$ of the preculture broth was inoculated into 40x1,000 ml baffled Erlenmeyer flasks containing $250 \mathrm{ml}$ of modified YMG broth (glucose $1 \%$, soluble starch $2 \%$, malt extract $0.5 \%$, yeast extract $0.5 \%$, and $\mathrm{CaCO}_{3} 0.05 \%$ ) and cultured for 7 days at $28^{\circ} \mathrm{C}$ on a rotary shaker with agitation at $125 \mathrm{rpm}$. The residue was partitioned with EtOAc three times and evaporated to remove the EtOAc. The crude extract was fractionated by reversed phase $\mathrm{C}_{18}$ vacuum column chromatography with a stepwise solvent system of $\mathrm{MeOH}: \mathrm{H}_{2} \mathrm{O}$ (20:80-100:0, each x 1 1). The 70\% fraction was further separated by RP-HPLC with $\mathrm{CH}_{3} \mathrm{CN}: \mathrm{H}_{2} \mathrm{O}$ (70:30) to yield ahpatinins $\mathrm{C}, \mathrm{E}$, and $\mathrm{G}$.

Cell culture and hypoxic conditions. HUVECs (ATCC ${ }^{\circledR} \mathrm{CRL}-$ $1730^{\mathrm{TM}}$ ) and human glioblastoma U87MG cells (Korean Cell Line Bank No. 30014; glioblastoma of unknown origin) were grown in EGM-2 and MEM supplemented with $10 \%$ FBS, respectively. The identity of the U87MG cell line was confirmed by STR profiling (D3S1358: 16,17; vWA: 15,17; FGA: 18,24; Amelogenin: X,Y; TH01: 9.3; TPOX: 8; CSF1PO: 10,11; D5S818: 11,12; D13S317: 8,11; D7S820: 8,9). All cells were maintained at $37^{\circ} \mathrm{C}$ in a humidified $5 \% \mathrm{CO}_{2}$ incubator. For hypoxic conditions, the cells were incubated in a hypoxic chamber (Forma Scientific) under $5 \% \mathrm{CO}_{2}$ and $1 \% \mathrm{O}_{2}$ balanced with $\mathrm{N}_{2}$.

Cell viability assay. HUVECs $\left(1 \times 10^{5}\right.$ cells/well) were seeded in a 12-well culture plate. Ahpatinins C, E, and G $(1-25 \mu \mathrm{M})$ were added to each well, and the cells were incubated for $72 \mathrm{~h}$. After $72 \mathrm{~h}$, the cells were stained with trypan blue and counted by a hemocytometer using an optical microscope (Olympus Corporation) at an x200 magnification.

Cell proliferation assay. HUVECs were seeded at a density of $3 \times 10^{3}$ cells/well in a 96-well culture plate and then treated 

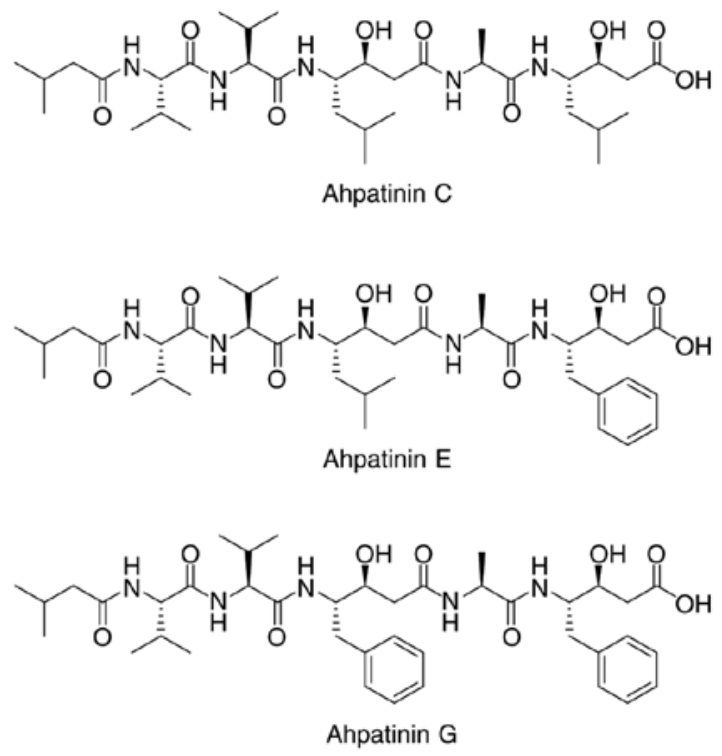

Figure 1. Chemical structures of ahpatinins C, E, and G.

with various concentrations $(1-25 \mu \mathrm{M})$ of ahpatinins $\mathrm{C}, \mathrm{E}$, and $\mathrm{G}$ in the presence of VEGF $(30 \mathrm{ng} / \mathrm{ml})$ for $72 \mathrm{~h}$. The cell proliferation was measured using a 3-(4,5-dimethylthiazol2-yl)-2,5-diphenyltetrazolium bromide (MTT) colorimetric assay.

Chemoinvasion assay. The invasiveness of HUVECs was examined using a Transwell chamber system with polycarbonate filter inserts with a pore size of $8.0 \mu \mathrm{m}$. The lower surface of the filter was coated with $10 \mu$ l of gelatin $(1 \mathrm{mg} / \mathrm{ml})$ for $1 \mathrm{~h}$ and the upper surface was coated with $10 \mu \mathrm{l}$ of Matrigel $(3 \mathrm{mg} / \mathrm{ml})$ for $2 \mathrm{~h}$. The serum-starved HUVECs $\left(6 \times 10^{4}\right.$ cells $)$ were seeded in the upper chamber of the filter, and ahpatinins $\mathrm{C}, \mathrm{E}$, and $\mathrm{G}(10$ and $20 \mu \mathrm{M})$ were added to the lower chamber in the presence of VEGF $(30 \mathrm{ng} / \mathrm{ml})$. The chamber was incubated at $37^{\circ} \mathrm{C}$ for $6 \mathrm{~h}$, and then the cells were fixed with $70 \%$ methanol at room temperature for $5 \mathrm{~min}$ and stained with hematoxylin and eosin (H\&E) at room temperature for $5 \mathrm{~min}$, respectively. The total number of cells that invaded the lower chamber of the filter was observed and counted using an optical microscope at an x400 magnification.

Adhesion assay. The cell-matrix adhesion assay was performed in a 24 -well culture plate coated with gelatin overnight at $4^{\circ} \mathrm{C}$. The HUVECs $\left(5 \times 10^{4}\right.$ cells/well) were cultured in each well in EGM-2 containing $1 \%$ FBS and treated with ahpatinins C, E, and $\mathrm{G}(10$ and $20 \mu \mathrm{M})$ in the presence of VEGF $(30 \mathrm{ng} / \mathrm{ml})$. After $3 \mathrm{~h}$, the unbound cells were carefully removed, and the attached cells were observed and counted under an optical microscope at an x200 magnification.

Capillary tube formation assay. The serum-starved HUVECs $\left(8 \times 10^{4}\right.$ cells) were placed on a surface containing Matrigel $(10 \mathrm{mg} / \mathrm{ml})$ from an angiogenesis kit (Ibidi $\mathrm{GmbH})$ and incubated with ahpatinins $\mathrm{C}, \mathrm{E}$, and $\mathrm{G}(10$ and $20 \mu \mathrm{M})$ for $8 \mathrm{~h}$ in the presence of VEGF (30 ng/ml). The morphological changes of the cells and tube formation were visualized under an optical microscope and photographed at an x200 magnification.
Chorioallantoic membrane (CAM) assay. The fertilized chick eggs were incubated in a humidified incubator at $37^{\circ} \mathrm{C}$ and $50 \%$ humidity for 3 days. Approximately $6-8 \mathrm{ml}$ of egg albumin was removed with a hypodermic needle, enabling the CAM and yolk sac to drop away from the shell membrane. After 2 days, the shell was punched out and peeled away. Thermanox coverslips (Nalge Nunc International) with or without ahpatinin $\mathrm{E}(10 \mu \mathrm{g} / \mathrm{egg})$ were air-dried and applied to the CAM surface. Two days later, $2 \mathrm{ml}$ of $10 \%$ fat emulsion (Sigma-Aldrich; Merck KGaA) was injected into the chorioallantois and the vascular images were observed by an optical microscope at an x200 magnification.

Tumor cell-induced chemoinvasion assay. A tumor cell-induced chemoinvasion assay was performed using an in vitro co-culture system based on the chemoinvasion assay. The U87MG cells were plated on the lower chamber and treated with ahpatinins $\mathrm{C}, \mathrm{E}$, and $\mathrm{G}(10$ and $20 \mu \mathrm{M})$ for $24 \mathrm{~h}$. The medium in each lower chamber was then replaced with fresh medium without ahpatinins $\mathrm{C}, \mathrm{E}$, and $\mathrm{G}$, and serum-starved HUVECs $\left(1 \times 10^{5}\right.$ cells) were placed in the upper chamber. The chamber was incubated at $37^{\circ} \mathrm{C}$ for $20 \mathrm{~h}$, and the HUVECs that invaded the lower chamber of the filter were analyzed using the same procedure as described in the chemoinvasion assay.

Tumor cell-induced capillary tube formation assay. To assess the effects of ahpatinins $\mathrm{C}, \mathrm{E}$, and $\mathrm{G}$ on tumor cell-induced capillary tube formation, a conditioned medium was obtained from the U87MG cells and used as the angiogenic stimulus for the tube formation of HUVECs. Briefly, the U87MG cells were treated with ahpatinins $\mathrm{C}, \mathrm{E}$, and $\mathrm{G}(10$ and $20 \mu \mathrm{M})$ for $24 \mathrm{~h}$, and then the medium was replaced with fresh medium without ahpatinins $\mathrm{C}, \mathrm{E}$, and $\mathrm{G}$. The conditioned medium was used in the in vitro tube formation assay.

Western blot analysis. Cells were lysed using RIPA buffer (Sigma-Aldrich; Merck KGaA) supplemented with a protease inhibitor cocktail (Roche Diagnostics) on ice. Protein concentrations of the extracts were determined using a BCA Protein Assay kit (Pierce; Thermo Fisher Scientific, Inc.). Equal amounts of cell lysate ( $40 \mu \mathrm{g} /$ lane) were separated by $10 \%$ sodium dodecyl sulfate-polyacrylamide gel electrophoresis (SDS-PAGE), and the separated proteins were transferred to polyvinylidene difluoride (PVDF) membranes (EMD Millipore) using standard electroblotting procedures. The blots were blocked in Tris-buffered saline with Tween-20 (TBST) containing 5\% skim milk at room temperature for $1 \mathrm{~h}$ and immunolabeled with primary antibodies against phospho-VEGFR2 (dilution 1:2,000), VEGFR2 (dilution 1:2,000), phospho-AKT (dilution 1:2,000), AKT (dilution 1:2,000), phospho-ERK1/2 (dilution 1:2,000), ERK1/2 (dilution 1:2,000), phospho-JNK (dilution 1:2,000), JNK (dilution 1:2,000), phospho-p38 (dilution 1:2,000), p38 (dilution 1:2,000),

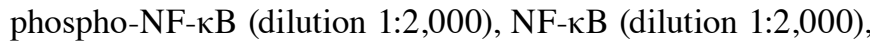
MMP-2 (dilution 1:2,000), MMP-9 (dilution 1:2,000), HIF-1 $\alpha$ (dilution 1:2,000), and $\beta$-actin (dilution 1:2,000) overnight at $4^{\circ} \mathrm{C}$. After washing with TBST three times, the membranes were incubated with horseradish peroxidase-conjugated anti-rabbit (dilution 1:3,000) or anti-mouse (dilution 1:3,000) secondary antibody for $1 \mathrm{~h}$ at room temperature. Immunolabeling was 
detected with an enhanced chemiluminescence (ECL) kit (Bio-Rad Laboratories, Inc.) according to the manufacturer's instructions. The band density was analyzed using ImageJ software (version 1.5; NIH).

Measurement of VEGF by enzyme-linked immunosorbent assay (ELISA). VEGF concentration in the media containing cells treated with ahpatinins $\mathrm{C}, \mathrm{E}$, and $\mathrm{G}(5,10 \mu \mathrm{M})$ was detected using a VEGF immunoassay kit (R\&D Systems, Inc.) according to the manufacturer's instructions. The results were expressed as the concentration of VEGF relative to the total amount of protein obtained from each well.

Statistical analysis. The data were presented as the mean \pm standard error (SE) of three independent experiments. Differences among groups were analyzed using the analysis of variance (ANOVA) with SPSS statistics package (SPSS 9.0; SPSS Inc.). Post hoc analysis was carried out by Tukey's test. A P-value of $<0.05$ was considered to indicate a statistically significant difference.

\section{Results}

Effects of ahpatinins $C, E$, and $G$ on the growth of HUVECs. Prior to assessing the antiangiogenic activities of ahpatinins $\mathrm{C}$, $\mathrm{E}$, and $\mathrm{G}$, the cytotoxic effects of ahpatinins $\mathrm{C}, \mathrm{E}$, and $\mathrm{G}$ on HUVECs were first investigated using the trypan blue exclusion method. As revealed in Fig. 2A, treatment with $1-25 \mu \mathrm{M}$ of ahpatinins $\mathrm{C}$, E, and $\mathrm{G}$ did not affect the viability of HUVECs. Thus, the effects of ahpatinins $\mathrm{C}, \mathrm{E}$, and $\mathrm{G}$ on in vitro angiogenesis at sub-toxic doses were evaluated. To assess the endothelial cell growth inhibitory activities of ahpatinins $\mathrm{C}$, $\mathrm{E}$, and $\mathrm{G}$, the proliferation assay was performed using the MTT colorimetric method. Treatment with VEGF (30 ng/ml) increased the proliferation of HUVECs up to $121.3 \%$, whereas ahpatinins $\mathrm{C}$, E, and $\mathrm{G}$ inhibited the VEGF-induced proliferation of HUVECs with different sensitivity to growth inhibition (Fig. 2B). Ahpatinin $\mathrm{C}$ inhibited cell growth at 5-25 $\mu \mathrm{M}$, and ahpatinin $\mathrm{G}$ exhibited a relatively weak proliferation inhibitory activity. Among them, ahpatinin E most effectively inhibited the growth of HUVECs at all the treated concentrations (1-25 $\mu \mathrm{M})$. These results indicated that ahpatinins $\mathrm{C}, \mathrm{E}$, and $\mathrm{G}$ suppressed the growth of HUVECs induced by VEGF without cytotoxicity.

Effects of ahpatinins $C, E$, and $G$ on in vitro angiogenesis. The effects of ahpatinins $\mathrm{C}, \mathrm{E}$, and $\mathrm{G}$ on the key angiogenic phenotypes such as endothelial cell invasion, adhesion, and tube formation, were next determined (20). Serum-starved HUVECs were stimulated by VEGF with or without ahpatinins $\mathrm{C}$, E, and $\mathrm{G}(10$ and $20 \mu \mathrm{M})$, and their inhibitory activities on VEGF-induced angiogenesis were observed through chemoinvasion, adhesion, and tube formation assays. As revealed in Fig. 3A-C, ahpatinins C, E, and G dose-dependently decreased the invasiveness, adhesion, and tube forming ability of HUVECs stimulated by VEGF. Among them, ahpatinin E exhibited the greatest antiangiogenic activity. These results demonstrated that ahpatinins $\mathrm{C}, \mathrm{E}$, and $\mathrm{G}$ significantly inhibited angiogenesis without exhibiting cytotoxicity on endothelial cells in vitro.
Effects of ahpatinin $E$ on in vivo angiogenesis. To further assess the maximum inhibitory effects of ahpatinin $E$ on in vitro and in vivo angiogenesis, a CAM assay was employed. Coverslips containing vehicle alone or ahpatinin $\mathrm{E}$ were located on the CAM surface, and the neovascularized zones were observed under a microscope. The ahpatinin E-treated CAMs had avascular zones as compared to the vehicle-treated ones (Fig. 4). The antiangiogenic response was calculated as the percentage of inhibited eggs relative to the total number of live eggs tested. The inhibition of neovascularization on the control coverslips was $6 \%(n=15)$, whereas ahpatinin E potently suppressed the angiogenesis of the CAMs (75\% at $10 \mu \mathrm{g} / \mathrm{egg}$, $\mathrm{n}=12$ ), without any rupture of the preexisting vascular tubes. In conclusion, these results demonstrated that ahpatinin E significantly inhibited angiogenesis both in vitro and in vivo without exhibiting cytotoxicity against endothelial cells.

Effects of ahpatinins $C, E$, and $G$ on VEGFR2-mediated signal transduction. VEGF binding to VEGFR2 at the surface of endothelial cells leads to dimerization and autophosphorylation of specific tyrosine residues in the cytoplasmic domain of VEGFR2 resulting in the subsequent activation of multiple downstream signaling mediators, such as AKT, MAPKs, and NF- $\mathrm{B}$ that promote angiogenesis (13-20). Thus, it was investigated whether the antiangiogenic activities of ahpatinins $\mathrm{C}, \mathrm{E}$, and $\mathrm{G}$ are associated with the suppression of VEGFR2-mediated signaling pathways. As revealed in Fig. 5, ahpatinins C, E, and G effectively suppressed the phosphorylation of VEGFR2, AKT, ERK1/2, JNK, p38, and $\mathrm{NF}-\kappa \mathrm{B}$ induced by VEGF, without affecting the total protein levels. Collectively, these data indicated that ahpatinins $\mathrm{C}$, $\mathrm{E}$, and $\mathrm{G}$ may exert antiangiogenic activities by inhibiting VEGFR2-mediated downstream signaling cascades in HUVECs.

Effects of ahpatinins $C, E$, and $G$ on MMP-2/-9 expression. MMPs degrade various ECM proteins present in the blood vessel basement membrane during angiogenesis (33). Therefore, the effects of ahpatinins $\mathrm{C}, \mathrm{E}$, and $\mathrm{G}$ on the expression of MMP-2/-9 stimulated by VEGF were examined. As revealed in Fig. 6, ahpatinins C, E, and G significantly decreased the expression levels of MMP-2 and MMP-9 in HUVECs, indicating that the antiangiogenic effects of ahpatinins $\mathrm{C}, \mathrm{E}$, and $\mathrm{G}$ may be associated with the downregulation of MMP-2/-9 expression.

Effects of ahpatinins $C, E$, and $G$ on tumor cell-induced angiogenesis. Since tumor angiogenesis is a critical hallmark of tumor growth and metastasis, blocking tumor-induced angiogenesis is a promising strategy in limiting cancer progression $(34,35)$. To evaluate whether ahpatinins $\mathrm{C}, \mathrm{E}$, and $\mathrm{G}$ inhibit tumor cell-induced angiogenesis, the effects of ahpatinins $\mathrm{C}, \mathrm{E}$, and $\mathrm{G}$ on the invasion and tube formation of HUVECs stimulated by U87MG glioblastoma cells were examined. As revealed in Fig. 7A, the HUVECs co-cultured with U87MG cells exhibited significant invasion compared to HUVECs alone. In contrast, when U87MG cells were treated with $20 \mu \mathrm{M}$ of ahpatinins $\mathrm{C}$, E, and $\mathrm{G}$, the induced invasion of HUVECs was completely inhibited. In addition, the tube formation of HUVECs was increased by the conditioned 
A

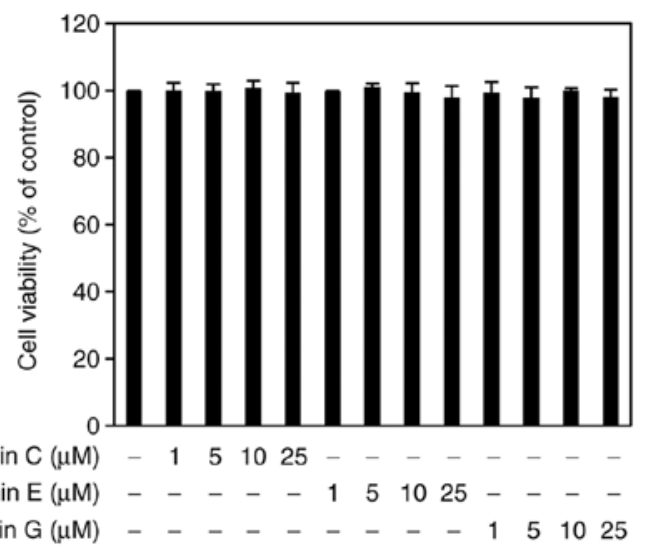

B

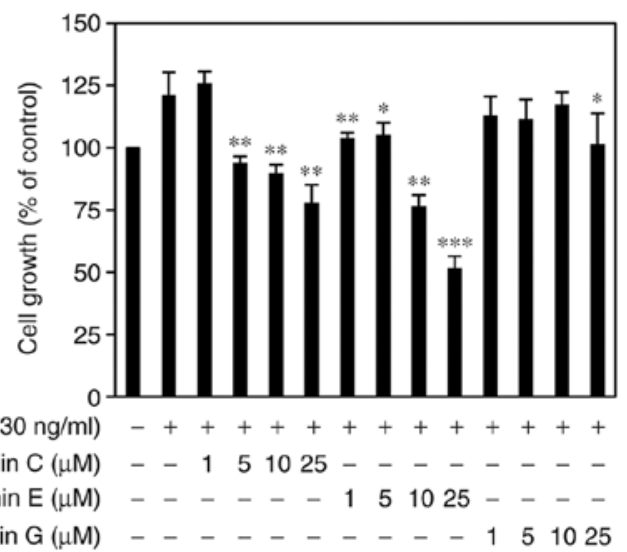

Figure 2. Antiproliferative activities of ahpatinins C, E, and G in HUVECs. (A) The effects of ahpatinins C, E, and G on the cytotoxicity of HUVECs. Cells were treated with the various concentrations $(1-25 \mu \mathrm{M})$ of ahpatinins $\mathrm{C}, \mathrm{E}$, and $\mathrm{G}$ and incubated for $72 \mathrm{~h}$. Cell viability was measured by the trypan blue assay. (B) The effects of ahpatinins C, E, and G on the growth of HUVECs. Cells were treated with ahpatinins C, E, and G (1-25 $\mu \mathrm{M})$ in the presence of VEGF (30 ng/ml) and incubated for $72 \mathrm{~h} .{ }^{*} \mathrm{P}<0.05,{ }^{* *} \mathrm{P}<0.01$ and ${ }^{* * *} \mathrm{P}<0.001$ vs. the VEGF control. Each value represents the mean \pm SE from three independent experiments. HUVECs, human umbilical vein endothelial cells; VEGF, vascular endothelial growth factor.
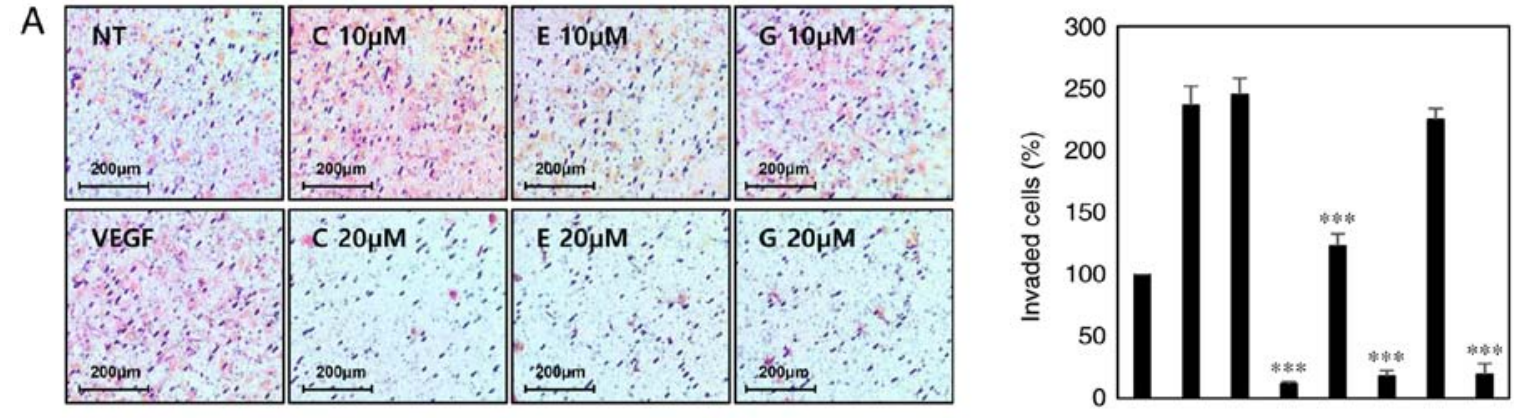

B
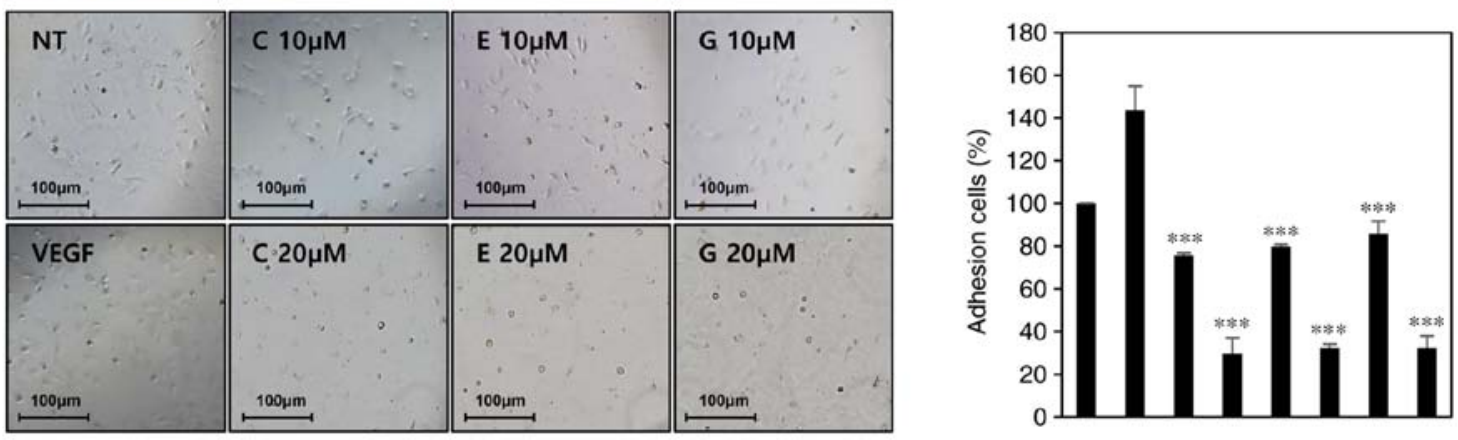

C
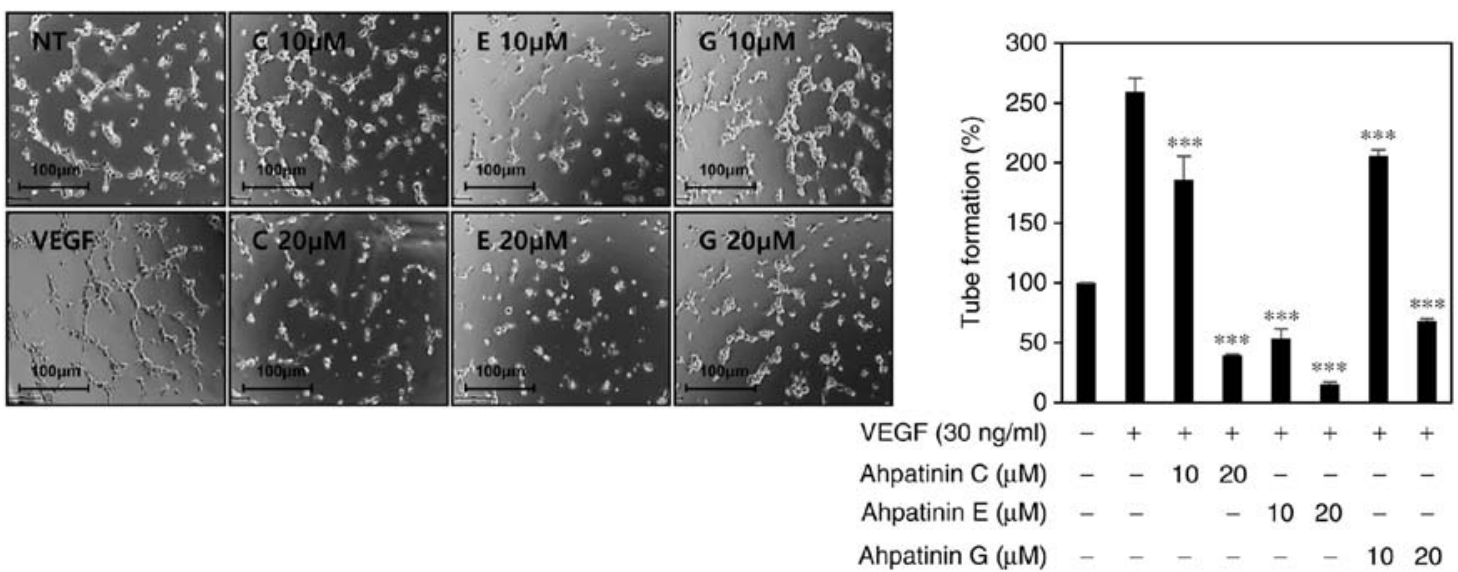

Figure 3. In vitro antiangiogenic activities of ahpatinins $\mathrm{C}$, E, and $\mathrm{G}$ in HUVECs. (A-C) The inhibitory effects of ahpatinins $\mathrm{C}, \mathrm{E}$, and $\mathrm{G}$ on the (A) invasion, (B) adhesion, and (C) tube formation of HUVECs induced by VEGF. Serum-starved HUVECs were stimulated with VEGF (30 ng/ml) in the presence or absence of ahpatinins $\mathrm{C}, \mathrm{E}$, and $\mathrm{G}(10$ and $20 \mu \mathrm{M})$. The basal levels of invasion, adhesion, and tube formation of HUVECs that were incubated in serum-free medium without VEGF were normalized to $100 \%$. ${ }^{* * *} \mathrm{P}<0.001$ vs. the VEGF control. Each value represents the mean \pm SE from three independent experiments. HUVECs, human umbilical vein endothelial cells; VEGF, vascular endothelial growth factor. 

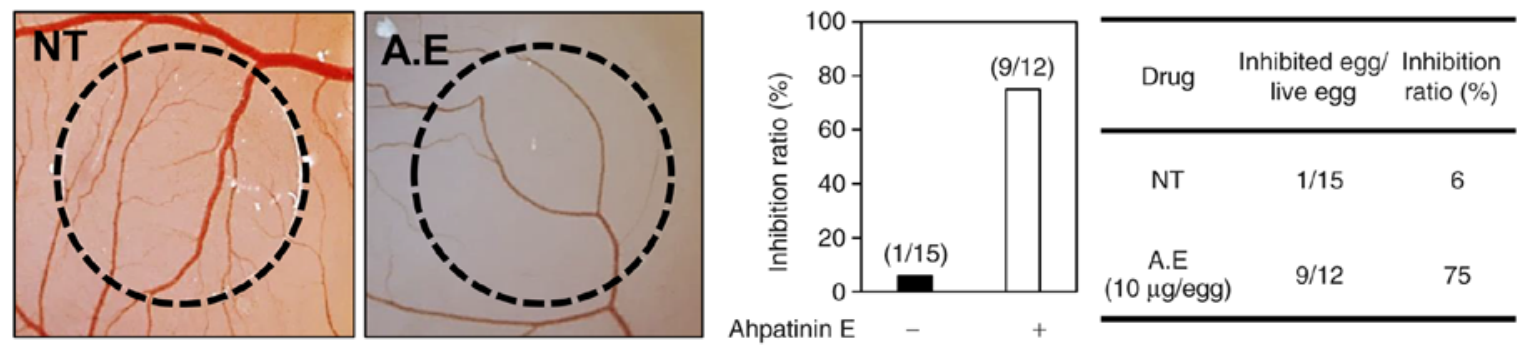

Figure 4. In vivo antiangiogenic activity of ahpatinin E in CAMs. Fertilized chick eggs were maintained in a humidified incubator at $37^{\circ} \mathrm{C}$. At embryonic day 4.5 , coverslips loaded with vehicle alone or ahpatinin E (10 $\mu \mathrm{g} / \mathrm{egg})$ were applied to the CAM surface. Two days later, the chorioallantois was observed under a microscope. Calculations were based on the ratio of inhibited eggs relative to the total number of live eggs. CAMs, chorioallantoic membranes.
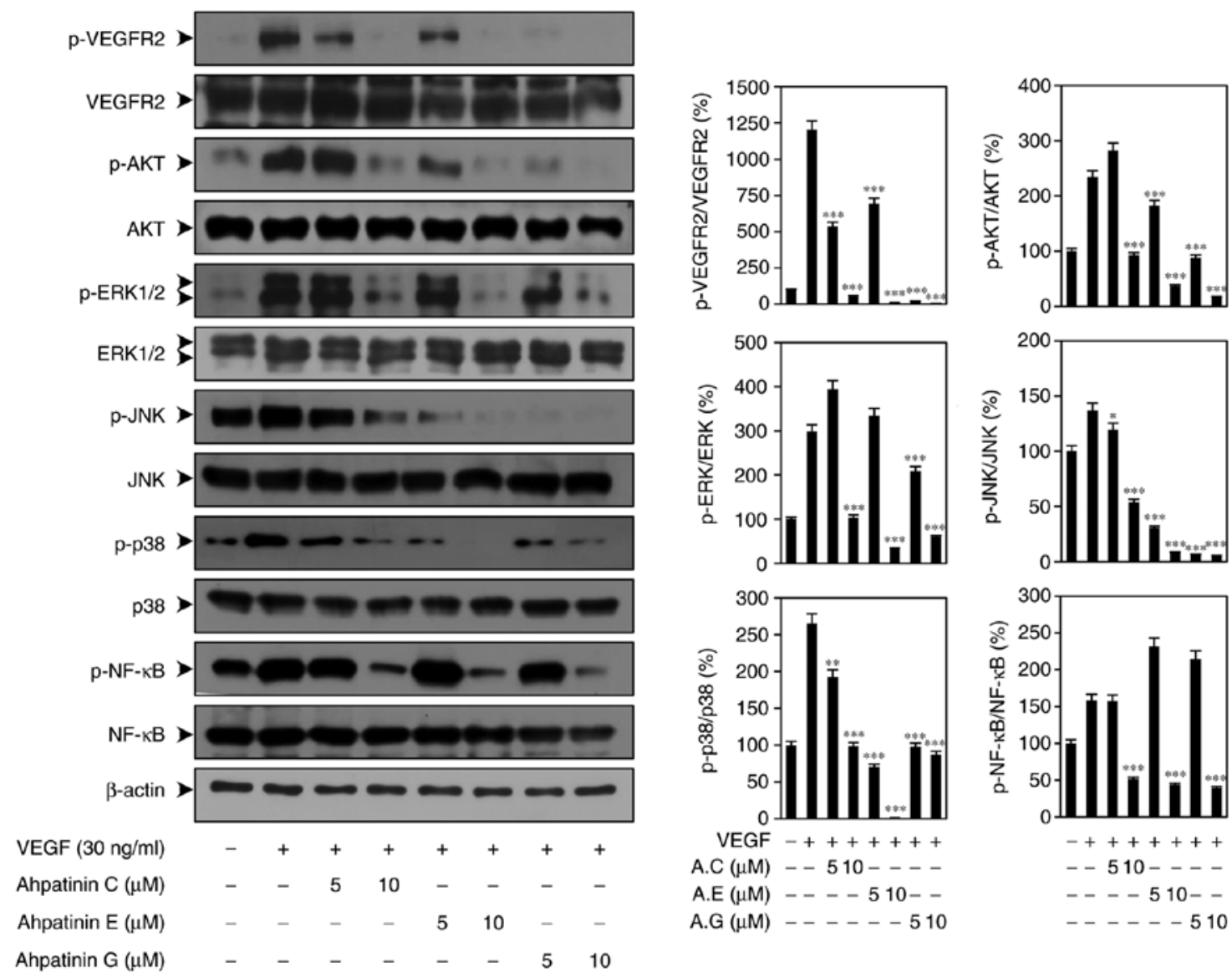

Figure 5. Downregulation of VEGFR2-mediated signaling by ahpatinins C, E, and G. Serum-starved HUVECs were pretreated with ahpatinins C, E, and G $(5$ and $10 \mu \mathrm{M})$ for $1 \mathrm{~h}$ and then stimulated with VEGF $(30 \mathrm{ng} / \mathrm{ml})$ for $10 \mathrm{~min}$. Protein levels were detected by western blot analysis. The level of $\beta$-actin was used as an internal control. ${ }^{*} \mathrm{P}<0.05,{ }^{* *} \mathrm{P}<0.01$ and ${ }^{* * *} \mathrm{P}<0.001$ vs. the VEGF control. Each value represents the mean $\pm \mathrm{SE}$ from three independent experiments. VEGFR2, VEGF receptor 2; HUVECs, human umbilical vein endothelial cells; VEGF, vascular endothelial growth factor.

medium obtained from U87MG cells compared to the control (medium only), whereas conditioned medium obtained from the U87MG cells treated with ahpatinins $\mathrm{C}, \mathrm{E}$, and G, effectively prevented the induced tube formation of HUVECs (Fig. 7B). These data revealed that ahpatinins $\mathrm{C}, \mathrm{E}$, and $\mathrm{G}$ could inhibit tumor cell-induced angiogenesis.

Effects of ahpatinins $C, E$, and $G$ on hypoxia-induced HIF-1a protein expression. Activation of HIF-1 $\alpha$ in the hypoxic tumor cells results in an increased expression of proangiogenic growth factors such as VEGF $(36,37)$. To confirm the role of HIF-1 $\alpha$ in mediating the antiangiogenic effects of ahpatinins $\mathrm{C}, \mathrm{E}$, and
G, the inhibitory activities of ahpatinins $\mathrm{C}, \mathrm{E}$, and $\mathrm{G}$ on the HIF-1 $\alpha$ expression of U87MG glioblastoma cells were determined. As revealed in Fig. 8A, treatment with 10 and $20 \mu \mathrm{M}$ of ahpatinins $\mathrm{C}, \mathrm{E}$, and $\mathrm{G}$ decreased the hypoxia-induced accumulation of HIF-1 $\alpha$ protein in U87MG cells. Furthermore, the effects of ahpatinins C, E, and G on the expression of VEGF induced by hypoxia were investigated. Ahpatinins C, E, and $\mathrm{G}(10 \mu \mathrm{M})$ also reduced VEGF production by U87MG cells under hypoxic conditions (Fig. 8B). These results indicated that ahpatinins $\mathrm{C}, \mathrm{E}$, and $\mathrm{G}$ could suppress tumor angiogenesis through the downregulation of HIF-1 $\alpha$ and its downstream target gene, VEGF. 

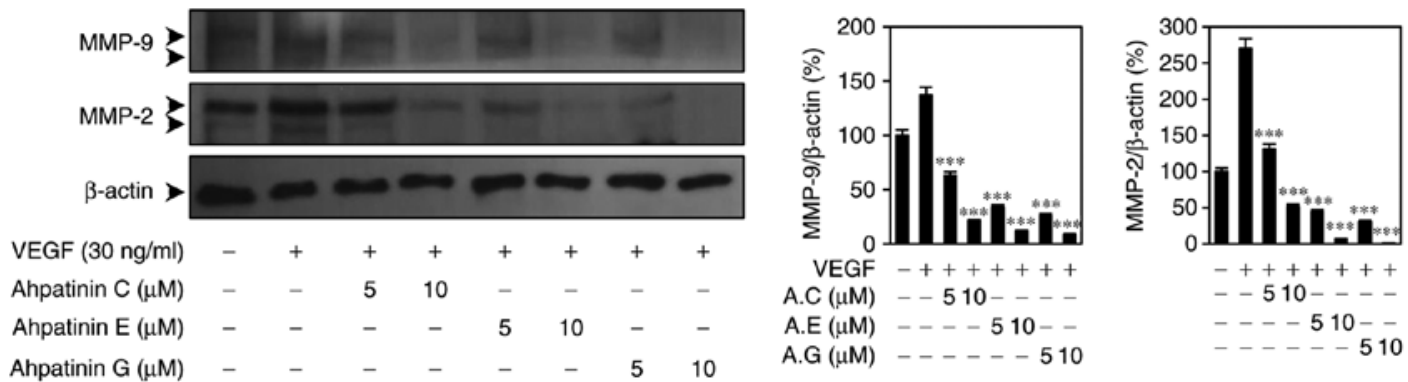

Figure 6. MMP-2 and MMP-9 inhibitory activities of ahpatinins C, E, and G. Serum-starved HUVECs were pretreated with ahpatinins C, E, and G $(5$ and $10 \mu \mathrm{M})$ in the presence of VEGF $(30 \mathrm{ng} / \mathrm{ml})$ for $24 \mathrm{~h}$. Protein levels were detected by western blot analysis. The level of $\beta$-actin was used as an internal control. ${ }^{* * *} \mathrm{P}<0.001$ vs. the VEGF control. Each value represents the mean $\pm \mathrm{SE}$ from three independent experiments. MMP, matrix metalloproteinase; HUVECs, human umbilical vein endothelial cells; VEGF, vascular endothelial growth factor.
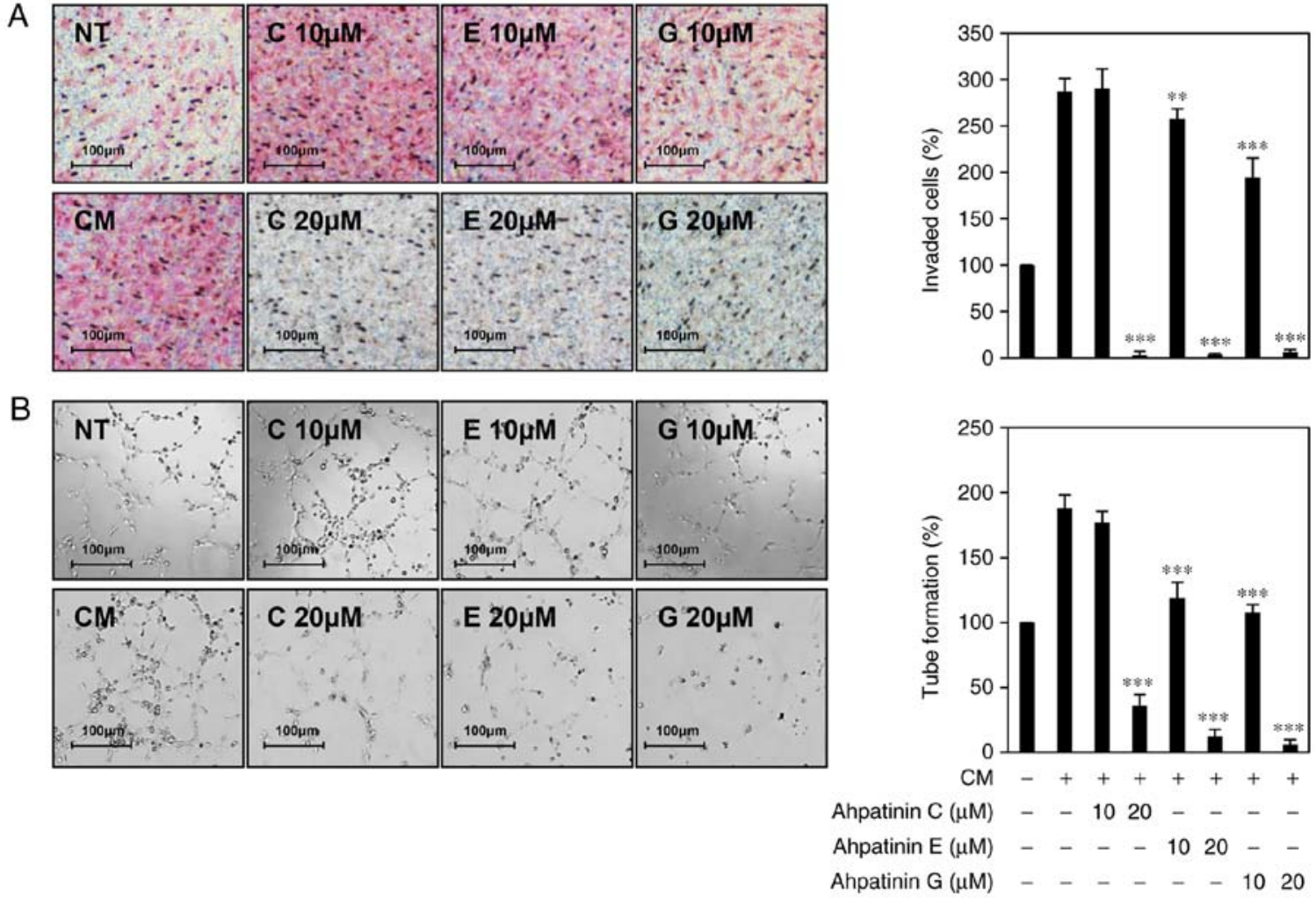

Figure 7. Effects of ahpatinins $\mathrm{C}, \mathrm{E}$, and $\mathrm{G}$ on tumor cell-induced angiogenesis. U87MG glioblastoma cell-induced angiogenesis was assessed using (A) an in vitro co-culture system based on the chemoinvasion assay and (B) a conditioned medium from tumor cells for in vitro tube formation assay. (A) The basal level of the invasiveness of HUVECs that were incubated in serum-free medium without U87MG cells was normalized to $100 \%$. ${ }^{* *} \mathrm{P}<0.01$ and ${ }^{* * * *} \mathrm{P}<0.001 \mathrm{vs}$. the control with untreated U87MG cells. (B) The basal level of the tube formation of HUVECs treated with non-conditioned medium without U87MG cells was normalized to $100 \%$. ${ }^{* * * *} \mathrm{P}<0.001$ vs. the conditioned medium from untreated U87MG cells. Each value represents the mean \pm SE from three independent experiments. HUVECs, human umbilical vein endothelial cells.

\section{Discussion}

The screening of new antiangiogenic drug candidates from microbial products has been successfully implemented for over a decade $(25,26,38)$. Recently, octaminomycins A and B, isolated from Streptomyces sp. RK85-270 were revealed to inhibit angiogenesis by reducing the protein stabilities of VEGFR2, AKT, and ERK1/2 and the activities of MMP-2 and MMP-9 in HUVECs (25). Two cyclic hexapeptides from the soil fungus Penicillium sp. FN070315, PF1171A, and PF1171C exerted their antiangiogenic activities by downregulating both VEGFR2 and HIF-1 $\alpha$ (26). Elaiophylin, which was originally isolated from Streptomyces melanosporus, exhibited a potent antiangiogenic activity through suppression of the activation of VEGFR2 and its downstream signaling mediators, AKT, ERK1/2, JNK, p38, and NF- $\mathrm{BB}$ (38). Through our continuing efforts in the search for potential angiogenesis inhibitors from microbial-derived natural products, the antiangiogenic effects and underlying molecular mechanisms of ahpatinins C, E, and G from a soil-derived Streptomyces sp. 15JA150 were newly revealed in the present study.

In previous studies, ahpatinins were reported to have inhibitory activities on renin and pepsin $(27,28)$. Ahpatinin C, an aspartic proteinase specific inhibitor, also suppressed 
A

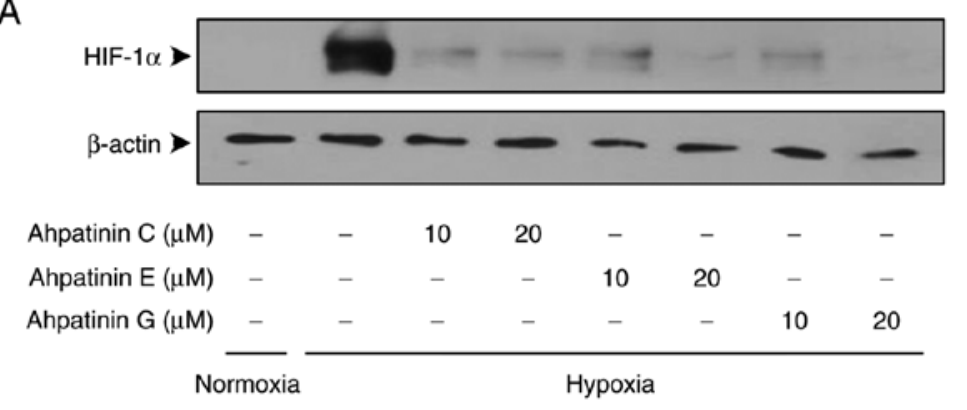

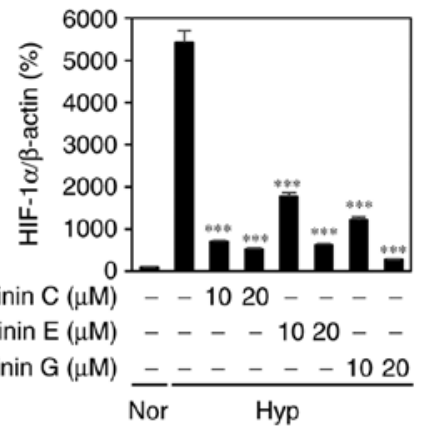

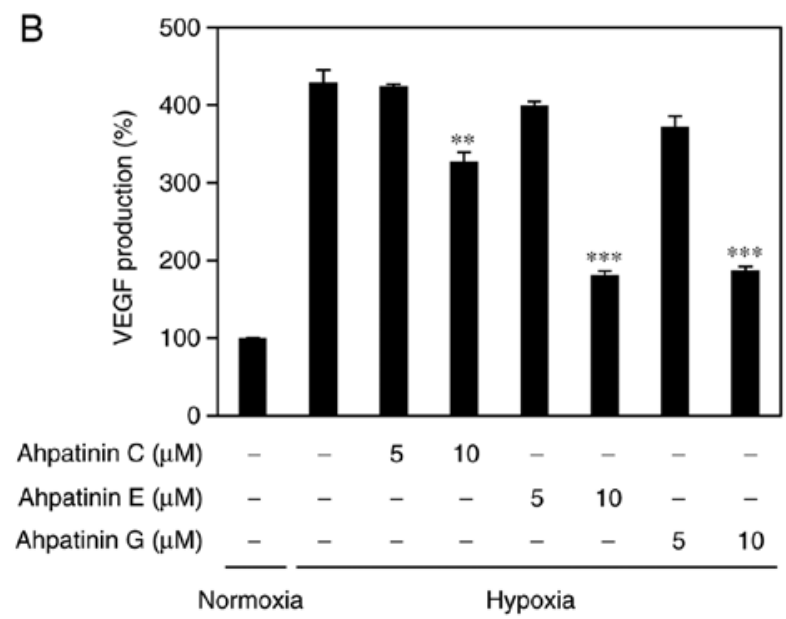

Figure 8. HIF-1 $\alpha$ inhibitory effects of ahpatinins C, E, and G. (A) The effects of ahpatinins C, E, and G on HIF-1 $\alpha$ protein accumulation. U87MG cells were pretreated with ahpatinins $\mathrm{C}$, E, and $\mathrm{G}(10$ and $20 \mu \mathrm{M})$ for $1 \mathrm{~h}$ and then exposed to $1 \% \mathrm{O}_{2}$ for 8 h. Protein levels were detected by western blot analysis. The level of $\beta$-actin was used as an internal control. (B) The effects of ahpatinins C, E, and G on VEGF expression. U87MG cells were pretreated with ahpatinins $\mathrm{C}$, E, and $\mathrm{G}(5$ and $10 \mu \mathrm{M})$ for $1 \mathrm{~h}$ and then exposed to $1 \% \mathrm{O}_{2}$ for $8 \mathrm{~h}$. The concentration of VEGF protein in the culture supernatant was determined by a VEGF specific ELISA. ${ }^{* *} \mathrm{P}<0.01$ and ${ }^{* * *} \mathrm{P}<0.001$ vs. the hypoxic control. Each value represents the mean $\pm \mathrm{SE}$ from three independent experiments. HIF-1 $\alpha$, hypoxia-inducible factor VEGF, vascular endothelial growth factor.

the receptor activator of $\mathrm{NF}-\kappa \mathrm{B}$ ligand (RANKL)-induced osteoclast differentiation through the downregulation of ERK signaling and expression of the nuclear factor of the activated T cells 1 (NFATc1) (39). Notably, ahpatinin C inhibited the invasion, tube formation, and MMP-9 activity of HUVECs and the angiogenesis of chick CAM induced by cathepsin D, which was identified to enhance tumor angiogenesis, growth, and metastasis $(29,40,41)$. However, the inhibitory activities of ahpatinins $\mathrm{C}, \mathrm{E}$, and $\mathrm{G}$ against VEGF-induced angiogenesis and their underlying molecular mechanisms have not yet been reported.

In the present study, it was demonstrated that ahpatinins $\mathrm{C}$, $\mathrm{E}$, and $\mathrm{G}$ effectively disrupted the key processes of angiogenesis stimulated by VEGF including the proliferation, invasion, adhesion, and tube formation of HUVECs, at sub-toxic concentrations. Moreover, ahpatinin E, which possessed a more potent antiangiogenic activity compared to that of ahpatinins $\mathrm{C}$ and $G$ in vitro, significantly suppressed the in vivo angiogenesis of CAM in chick embryos without any rupture of the preexisting blood vessels. Although ahpatinins C, E, and G exhibited inhibitory activities against VEGF-induced angiogenesis, further investigations identifying the relationship between their structures and activities could provide new insights into how they regulate angiogenesis.

Angiogenesis is promoted by the interactions between various proangiogenic factors and their receptors. VEGF, which is recognized as the major mediator of angiogenesis in cancer, can bind to and activate VEGFR1 (Flt-1) and VEGFR2 (KDR/Flk-1) (42,43). However, the tyrosine kinase activity of VEGFR2 is approximately 10-fold stronger than that of VEGFR1. Accordingly, the major proangiogenic signal generally originates from VEGFR 2 activated by VEGF. The binding of VEGF to VEGFR2 on the endothelial cell surface promotes receptor dimerization, enabling autophosphorylation of the intracellular tyrosine residues. The activation of VEGFR2 contributes to the phosphorylation of multiple downstream signaling molecules such as AKT, ERK1/2, JNK, p38, and NF- $\kappa$ B, and these molecules promote the proangiogenic cellular responses, including endothelial cell survival, proliferation, invasion, and migration, as well as vascular permeability and inflammation. Therefore, the blockade of VEGFR2-mediated signal transduction has been considered as a powerful therapeutic strategy for inhibiting angiogenesis. In the present study, the phosphorylation of VEGFR2 by VEGF was significantly inhibited by ahpatinins $\mathrm{C}, \mathrm{E}$, and $\mathrm{G}$, resulting in the suppression of the VEGF-induced activation of downstream signaling effectors, including AKT, ERK1/2, JNK, $\mathrm{p} 38$, and $\mathrm{NF}-\kappa \mathrm{B}$. These results indicated that ahpatinins $\mathrm{C}$, $\mathrm{E}$, and $\mathrm{G}$ exhibited antiangiogenic activities by blocking VEGFR2-dependent downstream signaling cascades in HUVECs. 
HIF-1 $\alpha$ plays a key role in the regulation of the expression of numerous genes involved in the metabolic adaptation to low oxygen, survival, and angiogenesis (21-23). The reduced HIF-1 $\alpha$ activity has been closely associated with promoted tumor angiogenesis and aggressive tumor growth in numerous cancers, resulting in the overexpression of VEGF and other genes that are involved in the induction of angiogenesis. HIF-1 $\alpha$ can be activated by tumor hypoxia, a wide range of tumor growth-promoting stimuli, and oncogenic pathways. HIF-1 $\alpha$ has, therefore, been suggested as a therapeutic target for impeding tumor angiogenesis. The present data revealed that ahpatinins C, E, and G suppressed the angiogenesis-promoting ability of U87MG glioblastoma cells present in a hypervascular tumor with a high level of HIF-1 $\alpha$ expression. In addition, ahpatinins $\mathrm{C}, \mathrm{E}$, and $\mathrm{G}$ reduced the hypoxia-induced accumulation of HIF-1 $\alpha$ protein in U87MG cells. They also decreased the VEGF production of U87MG cells under hypoxic conditions, indicating that ahpatinins $\mathrm{C}, \mathrm{E}$, and $\mathrm{G}$ could inhibit tumor cell-induced angiogenesis by downregulating HIF-1 $\alpha$ and its target gene, VEGF.

Collectively, the present findings provide a new outlook on the therapeutic aspect for ahpatinins C, E, and $\mathrm{G}$ as potent inhibitors of tumor angiogenesis through the dual blockade of the proangiogenic signaling mediated by VEGFR2 and the expression of HIF-1 $\alpha$. Further studies on how ahpatinins $\mathrm{C}$, $\mathrm{E}$, and $\mathrm{G}$ regulate both the VEGFR2 and HIF-1 $\alpha$ pathways will help to fully understand the antiangiogenic mechanisms of action of these natural microbial products.

\section{Acknowledgements}

The authors appreciate the Korea Basic Science Institute, Ochang, Korea, for providing the NMR and HRESIMS data.

\section{Funding}

The present research was supported by Basic Science Research Program through the National Research Foundation of Korea (NRF) funded by the Ministry of Education (NRF-2016R1D1A1B03932956) and the NRF grant funded by the Ministry of Science and ICT (no. 2019R1A2C1009033). This work was also supported by an International Joint Research Project (ASIA-16-011) of the NST (National Research Council of Science \& Technology) and the KRIBB Research Initiative Program funded by the Ministry of Science ICT (MSIT) of the Republic of Korea.

\section{Availability of data and materials}

The datasets generated and analyzed during the current study are available from the corresponding author upon reasonable request.

\section{Authors' contributions}

HJJ conceived and designed the experiments. JMH and JPJ performed the experiments and analyzed the data. HJJ, JHJ and JSA contributed reagents/materials/analysis tools. JMH and HJJ wrote the manuscript. JPJ, JHJ and JSA reviewed and edited the manuscript. All authors read and approved the final manuscript and agree to be accountable for all aspects of the research in ensuring that the accuracy or integrity of any part of the work are appropriately investigated and resolved.

\section{Ethics approval and consent to participate}

Not applicable.

\section{Patient consent for publication}

Not applicable.

\section{Competing interests}

The authors declare that they have no competing interests.

\section{References}

1. Ellis LM, Liu W, Ahmad SA, Fan F, Jung YD, Shaheen RM and Reinmuth N: Overview of angiogenesis: Biologic implications for antiangiogenic therapy. Semin Oncol 28 (5 Suppl 16): S94-S104, 2001.

2. Carmeliet P and Jain RK: Molecular mechanisms and clinical applications of angiogenesis. Nature 473: 298-307, 2011.

3. Weis SM and Cheresh DA: Tumor angiogenesis: Molecular pathways and therapeutic targets. Nat Med 17: 1359-1370, 2011

4. Wang Y, Li JX, Wang YQ and Miao ZH: Tanshinone I inhibits tumor angiogenesis by reducing STAT3 phosphorylation at TYR705 and hypoxia-induced HIF-1 $\alpha$ accumulation in both endothelial and tumor cells. Oncotarget 6: 16031-16042, 2015.

5. Jain RK: Antiangiogenesis strategies revisited: From starving tumors to alleviating hypoxia. Cancer Cell 26: 605-622, 2014.

6. Loges S, Schmidt T and Carmeliet P: Mechanisms of resistance to anti-angiogenic therapy and development of third-generation anti-angiogenic drug candidates. Genes Cancer 1: 12-25, 2010.

7. Ferrara N, Gerber HP and LeCounter J: The biology of VEGF and its receptors. Nat Med 9: 669-676, 2003.

8. Karkkainen MJ and Petrova TV: Vascular endothelial growth factor receptors in the regulation of angiogenesis and lymphangiogenesis. Oncogene 19: 5598-5605, 2000.

9. Kowanetz $M$ and Ferrara N: Vascular endothelial growth factor signaling pathways: Therapeutic perspective. Clin Cancer Res 12: 5018-5022, 2006.

10. Sachdev JC and Jahanzeb M: Evolution of bevacizumab-based therapy in the management of breast cancer. Clin Breast Cancer 8: 402-410, 2008.

11. Salter JT and Miller KD: Antiangiogenic agents in breast cancer. Cancer Invest 25: 518-526, 2007.

12. Abhinand CS, Raju R, Soumya SJ, Arya PS and Sudhakaran PR: VEGF-A/VEGFR2 signaling network in endothelial cells relevant to angiogenesis. J Cell Commun Signal 10: 347-354, 2016.

13. Jiang BH and Liu LZ: PI3K/PTEN signaling in angiogenesis and tumorigenesis. Adv Cancer Res 102: 19-65, 2009.

14. Koch S, Tugues S, Li X, Gualandi L and Claesson-Welsh L: Signal transduction by vascular endothelial growth factor receptors. Biochem J 437: 169-183, 2011.

15. Karar J and Maity A: PI3K/AKT/mTOR pathway in angiogenesis. Front Mol Neurosci 4: 51, 2011.

16. Gomes E and Rockwell P: p38 MAPK as a negative regulator of VEGF/VEGFR2 signaling pathway in serum deprived human SK-N-SH neuroblastoma cells. Neurosci Lett 431: 95-100, 2008.

17. Olsson AK, Dimberg A, Kreuger J and Claesson-Welsh L: VEGF receptor signalling-in control of vascular function. Nat Rev Mol Cell Biol 7: 359-371, 2006.

18. Kyosseva SV: Mitogen-activated protein kinase signaling. Int Rev Neurobiol 59: 201-220, 2004.

19. Noort AR, van Zoest KP, Weijers EM, Koolwijk P, Maracle CX, Novack DV, Siemerink MJ, Schlingemann RO, Tak PP and Tas SW: NF- $\kappa$ B-inducing kinase is a key regulator of inflammation-induced and tumour-associated angiogenesis. J Pathol 234: 375-385, 2014.

20. Risau W: Mechanisms of angiogenesis. Nature 386: 671-674, 1997.

21. Moulder JE and Rockwell S: Tumor hypoxia: Its impact on cancer therapy. Cancer Metastasis Rev 5: 313-341, 1987. 
22. Jubb AM, Buffa FM and Harris AL: Assessment of tumour hypoxia for prediction of response to therapy and cancer prognosis. J Cell Mol Med 14: 18-29, 2010.

23. Avni R, Cohen B and Neeman M: Hypoxic stress and cancer: Imaging the axis of evil in tumor metastasis. NMR Biomed 24 569-581, 2011.

24. Bernardes N, Seruca R, Chakrabarty AM and Fialho AM: Microbial-based therapy of cancer: Current progress and future prospects. Bioeng Bugs 1: 178-190, 2010.

25. Jang JP, Han JM, Jung HJ, Osada H, Jang JH and Ahn JS: Anti-angiogenesis effects induced by octaminomycins A and B against HUVECs. J Microbiol Biotechnol 28: 1332-1338, 2018.

26. Jang JP, Jung HJ, Han JM, Jung N, Kim Y, Kwon HJ, Ko SK, Soung NK, Jang JH and Ahn JS: Two cyclic hexapeptides from penicillium sp. FN070315 with antiangiogenic activities. PLoS One 12: e0184339, 2017.

27. Omura S, Imamura N, Kawakita K, Mori Y, Yamazaki Y, Masuma R, Takahashi Y, Tanaka H, Huang LY and Woodruff HB: Ahpatinins, new acid protease inhibitors containing 4-amino-3-hydroxy-5-phenylpentanoic acid. J Antibiot (Tokyo) 39: 1079-1085, 1986.

28. Sun Y, Takada K, Nogi Y, Okada S and Matsunaga S: Lower homologues of ahpatinin, aspartic protease inhibitors, from a marine Streptomyces sp. J Nat Prod 77: 1749-1752, 2014.

29. Hu L, Roth JM, Brooks P, Luty J and Karpatkin S: Thrombin up-regulates cathepsin D which enhances angiogenesis, growth, and metastasis. Cancer Res 68: 4666-4673, 2008.

30. Morjen M, Honoré S, Bazaa A, Abdelkafi-Koubaa Z, Ellafi A, Mabrouk K, Kovacic H, El Ayeb M, Marrakchi N and Luis J: PIVL, a snake venom kunitz-type serine protease inhibitor, inhibits in vitro and in vivo angiogenesis. Microvasc Res 95: 149-156, 2014.

31. Drewes CC, Dias RY, Hebeda CB, Simons SM, Barreto SA, Ferreira JM Jr, Chudzinski-Tavassi AM and Farsky SH: Actions of the kunitz-type serine protease inhibitor amblyomin-X on VEGF-A-induced angiogenesis. Toxicon 60: 333-340, 2012.

32. Zhu M, Li B, Wang J and Xiao R: The anti-angiogenic activity of a cystatin $\mathrm{F}$ homologue from the buccal glands of lampetra morii. Mar Drugs 16: E477, 2018.
33. Hass TL: Endothelial cell regulation of matrix metalloproteinases. Can J Physiol Pharmacol 83: 1-7, 2005.

34. Bergers $\mathrm{G}$ and Benjamin LE: Tumorigenesis and the angiogenic switch. Nat Rev Cancer 3: 401-410, 2003.

35. André T, Chastre E, Kotelevets L, Vaillant JC, Louvet C, Balosso J, Le Gall E, Prévot S and Gespach C: Tumoral angiogenesis: Physiopathology, prognostic value and therapeutic perspectives. Rev Med Interne 19: 904-913, 1998 (In French)

36. Badewiijns MM, van Vlodrop IJ, Vermeulen PB, Soetekouw PM, van Engeland M and de Bruïne AP: VHL and HIF signalling in renal cell carcinogenesis. J Pathol 221: 125-138, 2010.

37. Forsythe JA, Jiang BH, Iyer NV, Agani F, Leung SW, Koos RD and Semenza GL: Activation of vascular endothelial growth factor gene transcription by hypoxia-inducible factor 1 . Mol Cell Biol 16: 4604-4613, 1996.

38. Lim HN, Jang JP, Han JM, Jang JH, Ahn JS and Jung HJ: Antiangiogenic potential of microbial metabolite elaiophylin for targeting tumor angiogenesis. Molecules 23: E563, 2018.

39. Yoshida H, Okamoto K, Iwamoto T, Sakai E, Kanaoka K, Hu JP, Shibata M, Hotokezaka H, Nishishita K, Mizuno A and Kato Y: Pepstatin A, an aspartic proteinase inhibitor, suppresses RANKL-induced osteoclast differentiation. J Biochem 139: 583-590, 2006

40. Liaudet-Coopman E, Beaujouin M, Derocq D, Garcia M, Glondu-Lassis M, Laurent-Matha V, Prébois C, Rochefort H and Vignon F: Cathepsin D: Newly discovered functions of a long-standing aspartic protease in cancer and apoptosis. Cancer Lett 237: 167-179, 2006

41. Trincheri NF, Nicotra G, Follo C, Castino R and Isidoro C: Resveratrol induces cell death in colorectal cancer cells by a novel pathway involving lysosomal cathepsin D. Carcinogenesis 28: 922-931, 2007.

42. Zhang J, Zhao P, Fu Z, Chen X, Liu N, Lu A, Li R, Shi L, Pu P, Kang $\mathrm{C}$ and You Y: Glioma cells enhance endothelial progenitor cell angiogenesis via VEGFR-2, not VEGFR-1. Oncol Rep 20: 1457-1463, 2008.

43. Liang $\mathrm{X}, \mathrm{Xu} \mathrm{F}, \mathrm{Li} \mathrm{X}, \mathrm{Ma} \mathrm{C}$, Zhang $\mathrm{Y}$ and $\mathrm{Xu}$ W: VEGF signal system: The application of antiangiogenesis. Curr Med Chem 21: 894-910, 2014 